\title{
CONCEPTUAL COMPARISON OF TURKISH AND RUSSIAN ACCOUNTING SYSTEMS
}

\author{
DOI: 10.17261/Pressacademia.2020.1309 \\ JEFA- V.7-ISS.4-2020(6)-p.355-361
}

Hasan Talas ${ }^{1}$, Burcin Tutcu ${ }^{2}$

${ }^{1}$ Mediterenian University, Korkuteli Vocational School, Accounting and Tax, Antalya, Turkey. htalas@akdeniz.edu.tr, ORCID: 0000-0001-8590-273X

${ }^{2}$ Mediterenian University, Korkuteli Vocational School, Accounting and Tax, Antalya, Turkey. burcintutcu@akdeniz.edu.tr, ORCID: 0000-0003-1427-0741

\begin{tabular}{l} 
Date Received: September 3, $2020 \quad$ Date Accepted: December 1, 2020 \\
\hline To cite this document \\
Talas, H., Tutcu, BUrcin, (2020). Conceptual comparison of Turkish and Russian accounting systems. Journal of Economics, Finance and \\
Accounting (JEFA), V.7(4), p.355.361. \\
Permanent link to this document: $\underline{\text { http://doi.org/10.17261/Pressacademia.2020.1309 }}$ \\
Copyright: Published by PressAcademia and limited licensed re-use rights only.
\end{tabular}

\section{ABSTRACT}

Purpose- International Accounting Reporting Standards (IARS) brought a global perspective to accounting reporing. With those standards financial reporting have turned into a common jargon in the world and have become easily understandable by relevant persons around the world. Even though standards provided a common reporting possibility, the application of basic concepts of accounting differs according to countries. The formation of each country's accounting system has emerged as a result of the historical developments of the countries. Revealing these differences provides ease in understanding the accounting systems of countries. In this study basic concepts of Turkish and Russian accounting have been compared. Basic concepts of Turkish and Russian accounting were examined and similarities and differences were revealed.

Methodology - As a method, the related sources were examined by scanning the literature. Obtained data were compared. The comparison results are evaluated in the conclusion part.

Findings- As a result of our evaluation, it was revealed that although there are more similarities in the accounting perspective of the two countries, there are different concepts, and there are also similar concepts although they are expressed differently.

Conclusion- As a result, there are similarities in basic concepts such as Pecuniary and periodicity. Although expressed differently between the two countries, it has been observed that there are similar concepts. Finally, it was concluded that there are concepts that do not show similarity.

Keywords: Basic concepts of accounting, Turkish and Russian accounting system, accounting standards JEL Codes: M10, M14, M16

\section{HISTORICAL DEVELOPMENT OF ACCOUNTING}

It is known that accounting has been used in different ways since humanities existance. It is known that accounting records were encountered in Ancient Greece and Rome in the B.C. 3600s (Akdoğan vd, 1987:65). In Kuran Baccarat Verse 282 it is told that no matter how big or small it is all debts should be recorded. But it is known that the significant evolutions in double entry bookkeeping in accounting history has started at 15th century. In this period, the person who is in the field of accounting is Luca Pacioli. Luca Pacioli is known as the most important mathematician of the time and the person who taught accounting according to the double entry bookkeeping (Can, 2007:3).

\subsection{Historical Development of Accounting in Turkey}

The emergence of the accounting profession in Turkey is seen as government accounting in Ottoman Empire because private institutions are too few to need a registration system. But in governmental institutions there was a strong central accounting organization. With the growth of Ottoman Empire this organisation has grown and at the second half of 17th century this organisation has been divided into seven separate sections. In Ottoman Empire accounting organization, a method called ladder method has been used and it is known that the training is done in the form of master apprentice relationship. Due to all these reasons, it is not possible to find any teachings books written in the Ottoman Empire (Güvemli vd, 2013:22). 
Due to the capitulations given to the French during the reign of Suleiman the Magnificent, many commercial and economic relations were established with the French. Because of this reason, the French school was observed in accounting practices in these periods. The French school of accounting considered accounting as a means of collecting taxes on businesses and this reveals that there is a tax-based understanding in accounting practices in the early years of the Turkish Republic (Dinc. Vd, 2016:269).

With the Turkish Commercial Code adopted in 1926, balance sheet and profit and loss accounts, the way accounts are kept, the books that must be kept have taken their place in accounting practices (Öz ve Çevikcan, 2010: 116).

It was formed by the Uniform Accounting System Application Commission, which was established in 1971. It was made ready by taking into account the suggestions and opinions of the State Economic Enterprises (SEE). Uniform Accounting System has started to be implemented as of the date of 7.7.1971 and with the decision numbered 7/2767, twenty seven SEES as of 1.1.1972 (Sevilengül, 2013: 14).

On date 13.06.1989 Law No. 3568 on Independent Accountancy, Independent Accountant and Financial Consultancy and Certified Public Accountant entered into force. With this development, the profession has a legal infrastructure. Following this law, the General Communiqué on Accounting System Implementation (MSUGT) was published on 26.12.1992. This communiqué, which must be implemented since 1994, is accepted as a turning point for the private sector.

With globalization, the need for a common accounting language has begun to emerge. In 1994, Turkey Accounting and Auditing Standards Board (TMUDESK) was formed. TMUDESK, based on the International Accounting Standards considering the practice and legislation in Turkey has issued 19 standards (Ayboğa, 2002: 48; Kocamaz, 2012: 116).

In 1999 to replace TMUDESK Turkey Accounting Standards Board (TMSK) has been established. Accounting practices in Turkey during this period showed an improvement in a composite structure under the influence of the United States and European countries (Güvemli, 2001: 13). In 2011, TMSK was abolished and Public Oversight Accounting and Auditing Standards Institution (KGK) was established. Currently all regulations are carried out by the KGK.

\subsection{Historical Development of Accounting in Russia}

Accounting in Russia has changed over time due to reasons like, Russia having a wide country area, its diverse ethnic cultures and the administrative changes in the country. In Russia, the accounting system in general is gathered under three main headings. These are classified as accounting in the Russian Empire, accounting in the Soviet period, and accounting in the modern period.

Russian Empire period is divided in three main period. First period is pre-reform period. This period is the primitive recording system period which has lasted between year 862 to first centuries and in this period incomes generated from trade and revenues generated from taxes(tributes) have been recorded. In this period, as any farm was considered the property of the prince to which it was affiliated, the size of the taxes collected was not taken under a certain limit (rate). Second period refers to reforms which has been made between 18th century and I. Peter regin. In this period, the word accountant was taken from Swedish and entered the table of titles approved by I. Peter dated 24.01.1722 as a title under the archivist and actuary in colleges. The first rules of accounting are found in the regulations made after the introduction of the word accountant in Russian literature. Third period is the New-Reforms period. The continuation of the tradition that emerged in this period, its development with new reforms, the printing of accounting journals and the formation of scientific theories were seen. First Russian accounting book "Key Of The Trade" have been translated from English and published at year 1783 (Petrov A.M., Limar M.P, 2013: 59). Russian Empire preserved the traditional accounting culture despite being affected from double-entry bookkeeping system of Europe. Russian Empire did not take Europeian Accounting System as a whole new system but only put Russian accounting into the harmonization process. It is known that the double-entry bookkeeping method has been implemented in commercial enterprises in the 19th century Russia. In early 20th century the number of accounting schools in Russia have been increased and in year 1889 the first economics department have been opened. In Russian Empire period Russian Accounting System have been affected from French, German and Italian Accounting Schools.

In general, accounting continued in the pre-revolutionary period in the USSR. However, the 1917 revolution led to major socio-economic changes that could not affect accounting management. For this reason, there have been developments in the accounting system that strengthen the control of the central government in more detail. Due to changes in political side, accounting systems have been revised.

As a result, an account plan covering all sectors was developed and the obligation to use the same accounting terms was imposed. A socialist accounting system has been introduced as a result of only the state taking part in businesses (Pekdemir ve Akgün 1999, 4). The Central State Accounting Department was established on December 5, 1917, and with the Accounting 
Regulation published on July 13,1918 , the state accounting transition was made from the budget system to the double-sided recording method. Although accounting was completely standardized in the Soviet period, revision work began with the increase in the number of foreign companies (Sultanhanova. Vd, 2019,2).

In the modern era, the Russian accounting system needed a radical change. Harmonization for the standards started in 1998, and they made progress by publishing 20 standards. At the end of 2018, Russian standards and IFRS were compliant. It is known that public companies, banks, insurance companies arrange their financial statements in accordance with IFRS in today's Russia.

In the part so far, we have revealed the historical development of Turkish and Russian accounting. In the second part, we will introduce the basic concepts of accounting in the two countries. In the second part, we will introduce and compare the basic concepts of accounting in the two countries. In the results section, we will evaluate the results of the comparison.

\section{COMPARISON OF BASIC CONCEPTS OF TURKISH AND RUSSIAN ACCOUNTING}

The basic concepts of accounting explain the basic basis of accounting and its philosophy, in other words, the reason for its existence. All transactions on behalf of accounting form a basis on the concepts that are based on. This study will reveal the basic concepts of accepted accounting in two countries and make comparisons.

\subsection{Basic Concepts of Accounting in Turkey}

The basic concepts of accounting in Turkey for the first time published in 1970 State Economic Enterprises (SEE) has made only one chart of accounts for the mandatory use of the SEE and prepared for. In this study, basic concepts of accounting are determined as ten concepts. By adding two more concepts to these concepts, which have been in force for twenty-two years, twelve concepts that are accepted today have emerged. Today, following the determined scope of IAS made in the harmonization with the IFRS concept of twelve is considered as the basic concepts of accounting in Turkey.

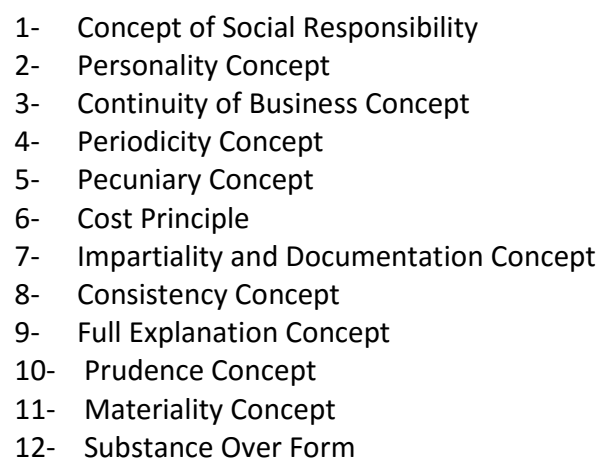

These concepts suggest that overall accounting in Turkey that it has a social responsibility of enterprises and have an independent personality of the partners and managers. While the measure unit of records is accepted as the local currency of the country, the cost basis is accepted in the accounting of the assets and services acquired by the enterprise. It expresses the need to take the essence of the transactions rather than their forms in reflecting on the accounting and making evaluations about them. Substance over form is used. It is stated in the basic concepts of accounting that the transactions should be fully explained and documented.

\subsection{Basic Concepts of Accounting in Russia}

The disintegration of the Soviet Union and the emergence of Russia as a new state on the world arena required important changes in the country's economic policies. At the same time, the transition from the guided management system to a market economy has further increased the need for radical changes in the country. As a result of these events, studies have been initiated in the country regarding the transition to international standards applied in the World (Akgün 2017, 3). In this direction, the Russian Federation has taken the first step. In Article 8 of the Federation of the Russian Federation No. 129-F3 dated November 21, 1996, the basic principles of accounting accounts are determined as follows ("The Federal Law 21.11.1996 N 129-F3").

1- Records of properties, assets (receivables), liabilities (debts) and economic transactions owned by businesses should be recorded in the "Ruble", the currency of the Russian Federation.

2- The assets owned by businesses should be recorded separately from the records of other companies within the organization. The record of each business must be in its own structure. 
3- According to the laws of the Russian Federation, as the opening registration of the enterprises as determined in the legislation, the accounting records should continue continuously in case of changes or until liquidation.

4- Records related to the properties, assets (receivables), liabilities (debts) and economic transactions owned by the enterprises should be kept in a double-entry bookkeeping, interconnected manner, depending on the accounting chart of accounts, and accounting records should be kept. Accounting data should match the transfers and balances in the accounting accounts in the overall assessment.

5- All economic transactions and inventory results should be transferred to accounting records in a timely manner without any skipping or exception.

6- Production costs (expenses) and capital investments should be recorded separately in the accounting records of enterprises.

The relevant article of law includes the concepts of pecuniary, personality, continuity, periodicity, correct classification and double-entry bookkeeping system.

The law dated November 21, 1996 was reorganized as the Accounting Regulation Principles in Article 20 of the Law No. $402-$ F3 dated 06.12.2011 and took the following form ("The Federal Law 06.12.2011 N 402-F3").

Accounting records should be made to the following principles.

1- Federal compliance and user needs must comply with industry standards, accounting (financial) reporting, and the level of accounting science and application development.

2- Accounting records must meet the requirements in an entirety.

3- Federal laws have the right to use / apply such governments for economic aspects, including finding simplified ways of accounting records, simplified accounting (financial) reporting.

4- The application of international standards is the basis of federal developments and industry standards.

5- Uniform applications should be determined for federal and industry standards.

6- Overriding approvals and powers in the area of accounting is subject to federal law.

International financial reporting standards have started to be applied rapidly around the world. The text of the law published by the Russian Federation on 06.12.2011 has taken a step towards compliance with these standards. These laws formed the basis for Russia's rapid adaptation to international financial reporting standards. In line with these laws, the basic concepts of Russian accounting are determined in the Russian literature as follows.

1- Pecuniary concept: Accounting records of assets, monetary liabilities (debts) and other economic transactions of businesses should be recorded as "Ruble", the currency of the Russian Federation (Mirosnicenko T.A., Bortnikova i.M.,Zubareva O.A.,2015: s.15).

2- Property seperation concept: The assets of businesses and the assets of other legal entities within the organization should be considered separately.

3- Continuty concept: The accounting records of the business start from the establishment date of the organization and include changes such as restructuring (bylaws, title, line of business, etc.) and continue until the liquidation or the end of the activities.

4- Double entry bookkeeping concept: The assets, monetary liabilities (debts) of the business and other economic transactions of the enterprise are recorded in the accounting chart of accounts with a double-entry bookkeeping system. This concept refers to the recording of the same amount to the debts and receivables of mutual accounts at the same time (Papalashev A.A,2019: s.27).

5- Periodicity concept: Accounting records should be reported regularly, periodically and in accordance with the workflow system.

6- Consistency concept: The transfers and leftovers in the accounting records should be appropriate in terms of evaluation / conclusion (logical inferences) calculations. At the same time, its continuity should be observed, its provisions should be preserved, and the methods and traditions of accounting practices should be focused on.

7- The concept of sufficiency (Integrty) and currentness: All economic transactions and inventory results should be recorded in timely accounting, without any skips and omissions. This concept also means that the accounting records reflect all economic activities (Litneva N.A., Malyavkina L.i.,Ferova T.V. 2015: s.22).

8- Concept of tracking of current expenditures and capital Investments in separate accounts: In the accounting of the organization, current production costs and capital investments should be considered separately. 
9- The concept of complex organisations system: The accounting system has a holistic, single-purpose and sustainable structure. In this system, financial and management accounting are interconnected and without one another, they interact with each other and there are also sub-systems. The accounting system covers practice and theory. For example, determining the income / profit figure to determine the tax amount to be paid, etc. is required.

10- Purpousefullness concept: The accounting system should provide business managers and external financial statement users with the information they need. This principle also means removing unnecessary accounting elements that will prevent decision makers from making the right decision.

11- The concept of reflection of economic factors: The basic truth in the accounting system is the reflection of economic life. Economic movements are recorded as income-expense in the appropriate books within the framework of regulations in the form of double-entry records.

12- The concept of recording: All economic movements of businesses are recorded by recovering related documents and accounting records.

13- Concept of privacy: The information obtained from the documents and accounting records of businesses are accepted as trade secrets under the responsibility of the persons specified in the law. In International Accounting Standards (IFRS), this principle means that the information reflected in the organization's reports should not harm the organization (Alborov P.A., 2016: s.54).

14- Concept of Integibility Of Knowledge: Information obtained from the accounting system should be useful for management. However, this cannot happen if the information cannot be understood by the users. Therefore, explanatory procedures should be applied to understand and interpret the accounting process.

15- Concept of reliability of information: The information obtained from accounting plays an important role in management's decisions. This concept includes increasing the reliability and efficiency of this information.

16- Concept of adaptation of accounting system to changes in management: The accounting system should be compatible with changes / new decisions in the management and management hierarchy. It should meet the structural changes and the need for new information.

17- Concept of adaptation of accounting systems to external changes: The accounting system should adapt to uncertainty or changes at risk outside the enterprise. For example, an increase in the tax rate, changes in inflation altitudes, changes in supply and demand figures, etc.

18- Concept of determining the principles of financial statements: This concept covers the principles of financial statements. The elements of the financial statements are determined as follows, Assets, debts, capital, income and expenses.

\subsection{COMPARASION OF TURKISH AND RUSSIAN BASIC CONCEPTS OF ACCOUNTING}

Looking at the accepted concepts of the two countries in terms of the basic concepts of accounting, it was determined in different concepts as well as the concepts that can accept similar. Comparison of concepts are given at Table 1.

Table 1: Comparison of Concepts

\begin{tabular}{|c|c|c|}
\hline Turkey & & \\
\hline \multicolumn{3}{|c|}{ Same Concepts } \\
\hline 1. Pecuniary Concept & & Pecuniary Concept \\
\hline 2. Consistency Concept & & Consistency Concept \\
\hline 3. Periodicity Concept & & Periodicity Concept \\
\hline 4. Personality Concept & & Property Seperatrion Concept \\
\hline 5. Continuity of Business Concept & & Continuity Concept \\
\hline \multicolumn{3}{|c|}{ Similiar Concepts } \\
\hline 6. Concept of Social Responsibility & & Concept of Reflection of Economic Factors \\
\hline
\end{tabular}




\begin{tabular}{|c|c|}
\hline 7. Full Explanation Concept & 7. Purpousefullness Concept \\
\hline & 8. Concept of Integibility of Knowledge \\
\hline \multirow[t]{2}{*}{ 8. Impartiality and Documentation Concept } & 9. Recording Concept \\
\hline & 10. Reliability of Informatıon Concept \\
\hline \multicolumn{2}{|c|}{ Different Concepts } \\
\hline 9. Cost Principle & 11. Double Entry Bookkeeping Concept \\
\hline 10. Prudence Concept & 12. The Concept of Integrity and Currentness \\
\hline 11. Materiality Concept & $\begin{array}{l}\text { 13. Concept of Tracking of Current } \\
\text { Expenditures and Capital Investments In } \\
\text { Separate Accounts }\end{array}$ \\
\hline \multirow[t]{5}{*}{ 12. Substance Over Form } & 14. Concept of Complex Organisation System \\
\hline & 15. Privacy Concept \\
\hline & $\begin{array}{l}\text { 16. Concept of Adaptation of Accounting } \\
\text { System to Changes in Managment }\end{array}$ \\
\hline & $\begin{array}{l}\text { 17. Concept of Adaptation of Accounting } \\
\text { System to External Changes }\end{array}$ \\
\hline & $\begin{array}{l}\text { 18. Concept of Determining Financial } \\
\text { Statements }\end{array}$ \\
\hline
\end{tabular}

As can be seen from Appendix 1, the concepts of pecuniary, consistency, periodicity, personality and continuity coincide exactly. Full explanation and social responsibility concepts in Turkey are similar to Concept of Reflection of Economic Factors, Concept of Integibility of Knowledge and purposefulness in Russia's concepts. Cost principle, prudence, materiality and substance over form concepts in Turkey differ from double entry, integrity and currentness, separate tracking, complex organisations system, privacy, adaptation to external and management changes and determining financial statements concepts in Russia.

\section{CONCLUSION}

It is seen that the concept of pecuniary with is common. The records made in Turkish lira in our country are registered in Russia in rubles. The pecuniary is accepted as the basic concept of accounting in two countries. It is also a common concept to the concept of consistency. The fact that the accounting records are consistent with each other and periodically has been adopted by both countries. The concept of periodicity is a common concept that the logic of reporting should be in certain periods, although the period 1 January - 31 December is accepted. The concept of personality, although this concept appears to be a distinction of property concept in Russia, logically, it contains the same logic as the concept of personality we accept. The concept of continuity of business, this concept has been adopted as the concept of continuity in Russia, but it emerges as a common concept since its businesses include the principle of adopting permanent ones. The concepts of social responsibility and explanation is like a whole of different concepts in Russia in a broad sense of these concepts accepted in our country. It is seen that these concepts are covered under the concepts of reflection, purposefulness and integibility of knowledge under our social responsibility and full explanation concepts.

The concept of impartiality and documentation is expressed in this concept with a few concepts in Russia, such as the concept of social responsibility. These concepts constitute the concepts of recording, the reliability of their information, and the concept of impartiality and documentation.

As a first difference, it seems useful in our discourse of chronology in the accounting process. The basic concept process, which started in the 1970s with single-order account plan studies in our country, started in Russia as of 1996 and efforts to establish country standards continue by considering IFRS. The reason for the difference between 1970 and 1996 is due to the differences in the political and administrative regimes of the countries.

While prudence, materiality, substance over form and the cost principle have been put forward as a special concept for our country, In Russia, they do not fully have provisions. On the other hand, double entry, integrity and currentness, separate tracking, complex organisations system, privacy, adaptation to external and management changes and determining financial statements concepts does not have provisions in Turkey. 


\section{REFERENCES}

Akdoğan, N., Aydın, H. (1987). Muhasebe Teorileri. Ankara, Gazi Üniversitesi Yayın No: 98.

Can, A. V. (2007). Luca Pacioli Muhasebenin Babası mıdır? Akademik Bakış, Uluslararası Hakemli Sosyal Bilimler Dergisi, (12).

Güvemli, O, Aytulun, A, Şişman, B. (2013). Türkiye'de Muhasebe Mesleğinin Gelişmesi ve İlk Meslek Örgütlenmesi: Türkiye Muhasebe Uzmanları Derneği - 1942. Muhasebe ve Finans Tarihi Araştırmaları Dergisi, (4) , 19-49.

Dinç, E. \& Atasel, O. Y. (2016). Türkiye'deki Muhasebe Anlayışının Gelişim Süreci ve Mevcut Durumun İncelenmesi. K.T.Ü. Sosyal Bilimler Enstitüsü Sosyal Bilimler Dergisi, (12), 267-283.

SEVILENGÜL, O. (2013). Genel Muhasebe. Ankara, Gazi Kitabevi.

Kocamaz, H. (2012). Uluslararası Muhasebe Standartlarının Dünyada Ve Türkiye'de Oluşum Ve Gelişim Süreci. Kahramanmaraş Sütçü İmam Üniversitesi İktisadi ve İdari Bilimler Fakültesi Dergisi, 2 (2) , 105-120.

Güvemli, O. (2001). Türk Devletleri Muhasebe Tarihi - Cumhuriyet Dönemi XX. Yüzyıl, 4. Cilt. İstanbul, Avcıol Basım Yayın.

Петров, А. М., \& Лымарь, М. П. (2013). История развития бухгалтерского учета в России и Китае. Международный бухгалтерский учет, (12), 56-63.

Sultankhanova, G., Ayanoğlu, Y., Yanık, S . (2019). Rusya'da Muhasebenin Tarihsel Gelişimi. Muhasebe Bilim Dünyası Dergisi, 21 (2) , $508-529$. DOI: $10.31460 / \mathrm{mbdd} .507747$

Akgün, L. (2017). Uluslararası Finansal Raporlama Standartlarına Uyum Sürecinde Rus Muhasebe Sistemi İle İlgili Yapılan Çalışmalar Ve Uygulamada Karşılaşılan Sorunlar Ve Çözüm Önerileri. Mali Çözüm, Mayıs-Haziran.

The Federal Law 21.11.1996 N 129-F3. (2020, March 1). Retrieved From

http://www.pravo.gov.ru/proxy/ips/?docbody=\&prevDoc=102165385\&backlink=1\&nd=102044306\&rdk=0

The Federal Law 06.12.2011 N 402-F3. (2020, March 1). Retrieved From

https://www.minfin.ru/ru/perfomance/accounting/accounting/legislation/legislation/?id_38=15014-

federalnyi_zakon_ot_06.12.2011 402-fz_o bukhgalterskom_uchete

Мирошниченко, Т.А., Бортникова, И.М. \& Зубарева, О.А. (2015). Бухгалтерский финансовый учет и отчетность. Ростов, изд-во ДонГАУ.

Папалашев, А. А. (2019). Принципы Организации Бухгалтерского Учета в Хозяйствующих Субъектах. In Актуальные Вопросы Права, Экономики и Управления (рр. 26-28).

Лытнева, Н.А., Малявкина, Л.И. \& Федорова, Т.В. (2015). Бухгалтерский учет : учебник. Москва, ИД «ФОРУМ» : ИНФРА-М.

Алборов, Р.А. (2016). Теория бухгалтерского учета. Ижевск, ФГБОУ ВО Ижевская ГСХА. 